\title{
The risk of exchange rate fluctuation and path choice in RMB
}

\author{
internationalization \\ Hongcheng Wang ${ }^{*}$, Xinting Bian \\ Nanjing University of Science and Technology, China \\ *Corresponding author: Hongcheng Wang, master, 904474794@qq.com
}

\begin{abstract}
At present, China has great influence in the world economy , the status of the RMB is also increasing rapidly. However, the level of internationalization of RMB is still lagging behind China's economic status. In recent years, internationalization of RMB has made great progress, the RMB has been included in the SDR currency basket and become the world currency. In the process of RMB internationalization, the fluctuation rate of RMB exchange rate has gradually become larger, and exchange rate fluctuation has a great influence on the process of RMB internationalization. The path choice of RMB internationalization is also an important factor
\end{abstract}

Key words: RMB; exchange rate; fluctuate; internationalization; path

\section{Introduction}

RMB internationalization is one of the core contents of China's current financial reform. In the process of internationalization of RMB, the control of exchange rate will gradually relax. The RMB has achieved two-way fluctuations from the unilateral appreciation of the past. RMB internationalization will have a certain degree of impact on China's exchange rate, while changes in exchange rates also react to the internationalization of the RMB. With the advancement of China's financial system reform and the strengthening of the overall strength of politics and economy, the internationalization of RMB is the trend. Therefore, the path choice of internationalization of RMB is the most concern of Chinese scholars. This paper will briefly introduce the development status and significance of RMB internationalization, and analyze the interaction between exchange rate fluctuations and RMB internationalization, then discuss the path choice of RMB internationalization, finally forecast the RMB exchange rate and put forward relevant suggestions. 


\section{The development of RMB internationalization}

Currency internationalization refers to a currency of some or all of the functions of the expansion by the original area to neighboring countries or regions and the world as a whole, which eventually evolved into the dynamic process of international regional until the global currency. Correspondingly, the internationalization of RMB means that the RMB can cross national boundaries and circulate abroad, and thus become the internationally recognized process of pricing, settlement and reserve currency.

The development of RMB internationalization is also the process of China's financial system opening to the outside world, financial regulation constantly relaxed, and the financial market constantly market-oriented. China began to implement the RMB international policy in 1993, from 1993 to 2011, China had carried out a number of financial reform. China had progressive realized the current account of the RMB freely convertible since 1993. In August 2011, China announced Hong Kong to become a RMB offshore center ${ }^{1}$. After 2011, the internationalization of the RMB has accelerated. On November 30, 2015, IMF announced the RMB into the SDR currency basket, which is a new breakthrough of internationalization of the RMB, while changing the pattern of the international monetary system, it will also bring a series of substantive benefits to its own economic development ${ }^{2}$. However, there are still some problems in the progress of RMB internationalization, like the imbalance of using RMB in import and export settlement. Generally speaking, over the years, the internationalization process of RMB has developed smoothly, and has made great progress, but there are still some potential risks.

\section{The significance of RMB internationalization}

Over the years, China has high economic growth and sustained trade surplus, however, the interest rate has not yet been completed marketization, resulting in financial market spreads, which Continues to cause false prosperity and appreciation pressure to the local currency, in order to temporarily resist the pressure of appreciation, the central bank has intervened in foreign exchange markets. With the expansion of the scale, the difficulty of monetary sterilization is increasing, and the structural imbalance of inflation and economic growth is intensified. In this process, China fall into a Stiglitz vicious circle, that is emerging markets use capital to support developed countries. For example, China absorbs excess capital (or hot money), then use foreign exchange reserves to invest in low yield US treasury bonds. In order to get rid of this dilemma and solve the problem of currency mismatch, it is necessary to 
change the status of non-international currency countries and promote the RMB to become the international financial market pricing and settlement tools. RMB become foreign investment and other central banks reserve currency, can reduce our foreign exchange reserves the scale. Besides, the People's Bank of the base currency and foreign exchange stocks can be decoupled to avoid excess liquidity deterioration.

Currency is a power. Each unit of currency represents the power to redeem a quantity of goods or services. Who has the power to issue coins, who can influence all the economic activities using the currency to trade, seigniorage is one of these powers. Furthermore, despite the fact that the issuer can not do whatever he wants, the change in his monetary policy and the fact that he has the power to change can itself restrict all users of the currency in various ways, all of the decisions need to take into account the effects of the currency's interest rate, exchange rate and other factors on their own trading and the value of the currency position they hold. In the case of the three world currencies dollar, JPY, EUR are Persistent downturn, expanding the scope of RMB settlement in international trade can change the embarrassing situation of China's "big trading country and small currency".

The internationalization of RMB indicates that RMB denominated financial products have become the investment tools of the major international financial institutions. Therefore, the RMB denominated financial market scale continues to expand. It is beneficial to enhance the voice of our currency, it symbolizes the broad influence of the RMB in the world economy. In addition, the RMB settlement transactions in international trade must reach a certain proportion, so that the role of RMB in the world monetary system is more important. It is beneficial to expanding the scale of trade in China and reducing exchange rate risk, RMB internationalization can provide local currency export credit for foreign importers and enhance export competitiveness, stimulate exports.

\section{The interaction of exchange rate fluctuation and RMB internationalization}

The process of currency internationalization is a long process, and it is also a difficult process. Currency internationalization is a double-edged sword. The failure of internationalization may seriously affect the financial system of china. Therefore, the process of RMB internationalization must be cautious. In this process, the internationalization of RMB will be affected by various factors, of which the impact of exchange rate fluctuations on RMB internationalization is the most direct and important.

When the RMB internationalization progresses smoothly, domestic and foreign residents 
increase demand for RMB, foreign RMB stock increases, which promote the appreciation of the $\mathrm{RMB}$ exchange rate. On the contrary, when the internationalization of the RMB encountered obstacles, foreign residents will lose confidence in the RMB and then sell RMB or RMB expressed financial assets.

Exchange rate fluctuations can reflect the foreign exchange market exchange rate changes, which can further affect the people's expectations and thus affect the direction of capital flows, thus affecting the internationalization of the RMB process. At the same time, the volatility of the exchange rate can also reflect the stability of a foreign currency, generally speaking, if a country's currency is stable, people are more willing to hold the country's currency, so foreign currency stock increases, Thus promoting the internationalization of a country's currency.

\section{RMB exchange rate volatility expectation under the background of RMB internationalization}

Exchange rate depends on the economic fundamentals of a country for a long time, but in the short run, it is often affected by irrational market expectations, resulting in market overshooting "herd effect". Although the RMB has been in a devaluation since 2014, we can not simply assume that the RMB will depreciate, It will take some time to observe. In the short term, there is a certain depreciation pressure on the RMB exchange rate, but the depreciation rate is limited. Capital flows and central bank intervention are key determinants of short-term RMB exchange rate. Since the expansion of RMB exchange rate floating range, China's exchange rate reform is in its infancy, RMB exchange rate ups and downs are normal. In the long run, the RMB does not have the basis of devaluation, two-way fluctuations will be the norm. As China's economic resilience continues to strengthen, the fundamentals of China's economy are good and do not support the devaluation of the RMB.

Compared with the global average economic growth rate, China's macro economy is still in a state of rapid development, which helps to enhance the status of the RMB in the international market. China still maintains the current account surplus, which provides support for the stability of the RMB exchange rate. Although affected by the economic crisis, China's economic growth slowed, but with the "The Belt and Road" strategy ${ }^{3}$, the establishment of Asian investment bank, Shanghai FTA positive practice, China's economic prospects remain bright, provide strong support for the RMB exchange rate expectations ${ }^{4}$. 


\section{The path choice of RMB internationalization}

Taking into account the volatility of the exchange rate on the internationalization of the RMB, the internationalization of the RMB should choose a sound way to avoid the domestic financial market turmoil because of rapid internationalization process.

The initial goal of RMB internationalization is the perimeter of $\mathrm{RMB}^{5}$. That is, the first development of the RMB into a regional currency, play cross-border settlement and pricing functions in the surrounding areas, reduce the cost of currency exchange within the region. In the initial stage of RMB internationalization, the government should introduce relevant policies to support cross-border trade settlement, realize the RMB convertible under the current account, strengthen the RMB currency settlement function, lay the foundation of RMB internationalization from regional to international Push forward. In 2009, the establishment of the Asian regional foreign exchange reserves in East Asian countries was an important step towards strengthening the financial cooperation and progressing towards the integration process in East Asian countries. RMB regionalization can be achieved by means of China's participation in economic and monetary cooperation in East Asia. It can take advantage of the current opportunities and cooperation of many countries and regions in East Asia to seek regional monetary cooperation. Through institutional regional monetary cooperation, the RMB can participate in the regional exchange rate system, Become the dominant currency of exchange rate cooperation.

When the RMB becomes the settlement currency of Asia and some other countries , the next step is to gradually realizing the goal of the RMB convertibility in the world and achieve RMB internationalization, constantly improve the level of RMB internationalization.

\section{Policy suggestion}

How far can the RMB be on the international road, depends most on the degree of development of China's economy. Therefore, the process of internationalization of the RMB must be compatible with the rhythm of the domestic financial system reform. In view of the current problems facing the internationalization of RMB, we propose the following suggestions for future financial reform:

First, RMB internationalization has a very important supporting conditions, that is, to improve the central bank's governance capacity, including the central bank monetary policy decision-making and implementation capacity, the central bank monetary policy credibility, market reputation, the central bank and market communication and guidance ability. China should pay attention to this issue.

Second, improve regulatory capacity and level, strengthen risk prevention. According to the Mundell Triangle impossible theory, the free flow of capital, exchange rate stability and independent monetary policy is difficult to exist at the same time ${ }^{6}$, which means that since the 
internationalization of the RMB, the difficulty of supervision is also greatly increased. The People's Bank of China needs to further promote the reform of the RMB exchange rate formation mechanism in China, appropriately expand the floating range of the RMB exchange rate against the US dollar, increase the volatility of the RMB exchange rate and realize the bidirectional fluctuation of the RMB .

Third, as the capital market is gradually open to the outside world, China should pay attention to the construction of the system and the supervision of the package. The opening of the capital market in the process of RMB internationalization is conducive to the rational allocation of resources in the domestic financial market. However, under the impact of exchange rate fluctuation, it will cause difficulties in supervision. Therefore, in the process of opening up the capital market, we should pay attention to the construction of good system Supervision of the package.

To sum up, in the context of the current devaluation of the RMB ,China should pay attention to maintain a stable offshore onshore market exchange, strengthen the expected management; further development of offshore market RMB-denominated financial products, expand investment products ${ }^{7}$; while paying attention to expanding the two-way fluctuation of exchange rate and appropriately increasing the tolerance of RMB exchange rate fluctuation, it is conducive to flexibly cope with the fluctuation of exchange rate in the offshore market and further promote the internationalization of RMB. the significance and importance of the reform of the financial market to the internationalization of the RMB is self-evident. We also need to soberly realize that the internationalization of RMB is not accomplished overnight, and it is full of various resistance ${ }^{8}$. In this case, we should vigorously develop and promote financial market, perfect financial products, improve the financial system, improve financial market supervision level, so that internationalization of the RMB can keep smoothly.

\section{References}

1. Zhou wuyang, Li yujia. Study on RMB regionalization and cooperation between Shenzhen and Hong Kong offshore markets[J]. Southern Finance,2011(5)

2. Chen yulu. The Belt and Road Initiative and RMB internationalization[J]. China Finance,2015,(19):40-42

3. Zheng liansheng. RMB's entry into SDR currency basket and its influence on financial reform [J].Financial Review,2016(1) 
4. Lin lefen. RMB internationalization and construct of The Belt and Road Initiative[J] . World economy and Politics,2015,(11):72-90

5. Tian tao. A Study on the Route Choice of RMB Internationalization [J]. Wuhan Finance,2015,(02):19-24

6. Sha wenbing, Liu hongzhong. RMB internationalization, exchange rate changes and exchange rate expectations[J]. International Finance Research,2014,(8):5-8

7. Zhou xiaochuan. The Development of Financial Reform and Its Internal Logic[J]. China Finance,2015,(19):39-42

8. Sha wenbing, Xiao mingzhi. A Study on the Economic Effect of Exchange Rate Fluctuation in the Process of RMB Internationalization[J]. World Economic Study,2016,(01):39-47 